\title{
Temperature requirements for the growth of immature stages of blowflies species, Chrysomya albiceps and Calliphora vicina, (Diptera:Calliphoridae) under laboratory conditions
}

\author{
Mojtaba Salimi ${ }^{1}$, Yavar Rassi ${ }^{1 *}$, Mohamadali Oshaghi ${ }^{1}$, Omid Chatrabgoun ${ }^{2}$, Mojtaba Limoee ${ }^{3}$ \\ and Sayena Rafizadeh ${ }^{4}$
}

\begin{abstract}
Background: In forensic entomology, a way to estimate Post Mortem Interval (PMI) is to use development data of the first colonizing insects on a dead body. Chrysomya albiceps and Calliphora vicina, two members of the family Calliphoridae, are the first waves of necrophagous insects that are the most entomologically important fly species because of its consistent time of arrival and colonization of the body following death. Regarding the bioclimatic, environmental conditions and difference in geographic population, it seems necessary to collect data about the forensically important species in each region. In this research, the growth rate of immature stages of $C$. albiceps and C.vicina was studied in controlled laboratory conditions.

Results: The results of this study showed that with increasing temperature, the duration of development was reduced. The highest period of development, for both species, is related to pupae stage and involves about half of the entire development period. The amount of Accumulated Degree Days (ADD) for the egg stage to mature of the species $C$. vicina, at two temperatures of $15^{\circ} \mathrm{C}$ and $20^{\circ} \mathrm{C}$, are calculated as 416 and $396 \mathrm{DD}$, respectively.

Conclusion: This study showed, temperature had significant effects on rate of the development on Chrysomya albiceps and Calliphora vicina and the amount of heat energy needed to development for these species is specific. Actually, the relationship between the development rate and temperature was significant and dependent to species and geographical regions.
\end{abstract}

Keywords: Forensic, Calliphoridae, Larva, Temperature, Iran

\section{Background}

When a dead body is discovered, the main question is to find the time spent on death. This question can be answered in two ways using entomology data: first, using the succession data of insect's taxa that have time and food preferences and are changed based on the stage corpse putrefaction; and second, using the development data of the oldest and largest maggots of the first

\footnotetext{
* Correspondence: rassiy@tums.ac.ir

${ }^{1}$ Department of Medical Entomology \& Vector Control, School of Public

Health, Tehran University of Medical Sciences(TUMS), Tehran, Iran

Full list of author information is available at the end of the article
}

colonizing species. Succession data are mostly used for the cases in which a long time has been spent on death while development data are mostly used for the cases in which a short time has been spent on death. Studies have shown that insect development is directly related to environmental data such as temperature and humidity. Degree day model using development data of necrophagous insect on the carcass particularly first colonizers and environmental data such as temperature can be estimate the time of death (Kumara et al., 2017; Bansode et al., 2016; Chua, 2013). As a microhabitat, the corpse is used differently by the insects that colonize the 
body. Some insects use body as food source and reproduction, some others as a place for prey and parasitization of larvae and others as a habitat. In terms of forensic entomology, all these arthropods provide some information and evidence on the crime scene. The most important insects in the forensic entomology that are attracted to the corpse immediately after death are two families of flies known as Calliphoridae and Sarcophagidae (Al-Mesbah et al., 2011; Al-Shareef \& AlQurashi, 2016). The number of different species of this family is variable based on the geoclimatic and environmental conditions of the region. In each region, the number of one species of this family may be more than the other ones based on environmental conditions. Thus, PMI is calculated based on the development stages of dominant species (Al-Shareef \& Al-Qurashi, 2016; Smith, 1986). Chrysomya albiceps is mostly found in temperate and subtropical regions during the hot months of the year and temperature plays a key role in determining the variation of its dispersion (Fig. 1) (Al-Shareef \& Al-Qurashi, 2016; Smith, 1986; Tabor et al., 2004; Grassberger et al., 2003). This species is reported to be seen in afro-tropical, oriental, south central America and southern Europe and the areas located at altitudes of $1300-3100 \mathrm{~m}$ above sea level (Queiroz, 1996; Szpila et al., 2008). In most of these researches, this species is known as primary species and is considered as the first colonizer that is responsible for using dead bodies (Al-Mesbah et al., 2011; Bharti \& Singh, 2003). Facultative predation, Competition and cannibalism are different nutrition strategies that are adopted in the second and third larvae stages of this species facing various conditions (Szpila et al., 2008; Faria \& Godoy, 2001). Calliphora vicina is a member of the family Calliphoridae which is considered as a eusynanthropic species with endophilic tendencies and it is mostly seen during the cold months (Fig. 1) (Faucherre et al., 1999). Temperature is one of the critical factors that is effective in laying activities and development of larvae of this species. It can be active within a range of $10-12^{\circ} \mathrm{C}$ to $28-30^{\circ} \mathrm{C}$ (Faucherre et al., 1999; Erzinclioglu, 1996; Williams, 1984). In different studies, this species is considered as the first and only colonizer on the corpse, especially during the cold months of the year (Bharti, 2009).

Generally, there is a bilateral relationship between temperature and development of insects. The insect growth is a linear function of temperature variation (Defilippo et al., 2013). The rate of development and growth of insect larvae can be obtained using different methods, the most common of which is to calculate ADD/ ADH (Grassberger \& Reiter, 2001; Marchenko, 1989; Anderson, 2000; Oshaghi et al., 2009). The difference in geographic populations of insects makes them tolerate a range of temperature, exclusive to each species, during different stages of growth. Therefore, ADD/ADH is different for the insect population of each geographic region (Davies \& Ratcliffe, 1994; Donovan et al., 2006). The goal of this research is studying the growth parameters of pre-mature stages of forensic dominant species, i.e. C.albiceps and C.vicina, under constant laboratory temperature conditions and calculating ADD for them as well as comparing the development data of these species with populations living in other geographical areas.

\section{Materials and methods}

\section{Sampling location and period}

This research was done under both field and laboratory conditions. The field of research was conducted in the Bisetoon protected area, west of Iran, 13 kilometers far of the city of Kermanshah, $34^{\circ} 24^{\circ} 37^{\circ} \mathrm{N}$ and $47^{\circ} 14^{\circ} 42^{\circ}$ E, comprising a land area of $54,950 \mathrm{~km}^{2}$ and elevation about $1320 \mathrm{~m}$ above sea level. The average precipitation here is $400-450 \mathrm{~mm}$ per year and the average maximum and minimum temperatures are $30^{\circ}-35^{\circ} \mathrm{C}$ and $-2^{\circ} \mathrm{C}$, respectively. The flora of this region is mostly meadow and it has four distinct seasons in terms of temperature conditions.

\section{Rearing in field conditions}

In this research, inbreeding rabbits, about $2.5 \mathrm{~kg}$ in weight, were used. The rabbits were first killed by chloroform and then, weighed and immediately transferred to the field. The carcasses were put in cages $(150 \times 90 \times 90)$ with $1.25 \mathrm{~cm}$ meshes with their floors

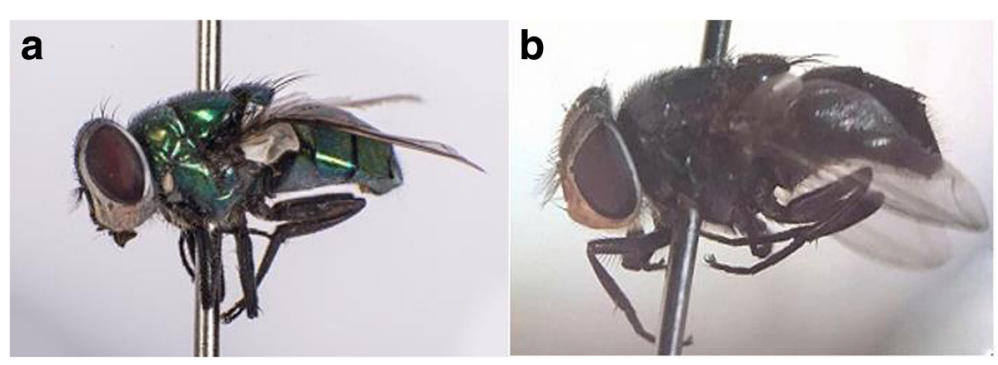

Fig. 1 Pictures of Chrysomya albiceps (a) and Calliphora vicina (b) 
being directly in contact with the ground. The sampling was done from mature flies using insect net through sweeping from the corpse in immature stages with forceps. The corpse had degeneration in four stages, i.e. decay, bloated, fresh and dry in the field and the duration for each stage depends on the season during which it happens. Eggs and larvae clusters of the stage one are collected from the corpse using forceps and put in transparent plastic containers $(15 \times 10 \times 10) \mathrm{cm}$ that have lace fabric lids for air conditioning. Each container is supplied with a $3 \mathrm{~cm}$ layer of sawdust, a piece of rabbit meat covered by an aluminum sheet and daily humidity. The goal was to detect the mature species as well as to compare the adults out of pupa with the sampled ones in terms of number. The adult samples were transferred to cages $(50 \times 50 \times 50) \mathrm{cm}$ with fabric laces containing rabbit meat substrate with humidity and a few hours later, the egg and larvae samples were put into other breeding containers and then transferred immediately to the laboratory of Kermanshah School of Public Health. In this study, larval and adult of blowflies were identified based on descriptive and pictorial keys (Szpilla, 2010a; Szpilla, 2010b).

\section{Rearing in laboratory conditions}

The identified samples were bred and evolved under constant-temperature conditions of the laboratory. In order to avoid making mistake during all breeding stages, both in the field and laboratory, rabbit meat substrate was used to feed the maggots. In the laboratory, the samples were put into incubator with constant temperature, humidity and photoperiod similar to the field conditions. Then, the growth stages of the samples were investigated regularly.

\section{Development zero (Dz) temperature}

The development of different growth stages of insects proceeds between two ranges of lower and upper development threshold temperature outside of which the growth stops. Development zero temperature or lower development threshold temperature is different based on the species, different stages of development of each species and geographic conditions. By reviewing previous studies, i.e. Marchenko, (Marchenko, 1989) Queiroz, (Queiroz, 1996) Grassberger and Reiter,(Grassberger \& Reiter, 2001) Richard et al., (Richards et al., 2008) and Al-Shareef and Al-Qurashi, (Al-Shareef \& Al-Qurashi, 2016) conducted in different geographic populations, some numbers were calculated for the Dz temperature of the species C.albiceps and regarding all of which an average temperature was determined for each stage as follows: egg stage to first larvae $\left(9.72{ }^{\circ} \mathrm{C}\right)$; larvae stage one to second stage $\left(11.14^{\circ} \mathrm{C}\right)$; second stage to third stage $\left(13^{\circ} \mathrm{C}\right)$; larvae stage three to pupal $\left(14.48{ }^{\circ} \mathrm{C}\right)$ and for pupal stage to adult $\left(14.32^{\circ} \mathrm{C}\right)$. Overall, $10.11^{\circ} \mathrm{C}$ and 15. $38^{\circ} \mathrm{C}$ were determined for the egg to adult and first larval to adult, respectively. Referring the studies done before, different temperatures were also suggested for the $\mathrm{Dz}$ temperature of the species C.vicina: Kamal (Kamal, 1958) $\left(\mathrm{Dz}=1^{\circ} \mathrm{C}\right)$; Vingradova (Vinogradova \& Reznik, 2015) and Marchenko (Marchenko, 1989) (Dz= $2^{\circ} \mathrm{C}$ ); Davies and Ratcliffe (Davies \& Ratcliffe, 1994) $\left(\mathrm{Dz}=3.5^{\circ} \mathrm{C}\right)$; Haskell (Haskell et al., 2000) $\left(\mathrm{Dz}=6^{\circ} \mathrm{C}\right)$; Ames and Tuner (Ames \& Turner, 2003) $\left(\mathrm{Dz}=1^{\circ} \mathrm{C}\right)$, Donovan et al., (Donovan et al., 2006) based on linear approximation estimation method $\left(\mathrm{Dz}=1^{\circ} \mathrm{C}\right)$ and Defilippo et al. (Defilippo et al., 2013) $\left(\mathrm{Dz}=1.6^{\circ} \mathrm{C}\right)$ were concidered. In this study, we considered $2^{\circ} \mathrm{C}$ for all the growth stages of the species C.vicina. ADD was calculated in the laboratory based on the formula suggested by Wilson and Barnett (Gennard, 2007):

$\mathrm{ADD}=$ Days $\left(\mathrm{T}_{\text {constant }}-\mathrm{T}_{\text {basment }}\right)$.

\section{Results \\ Rearing in field conditions}

The results obtained from breeding eggs and larvae clusters that were collected from the rabbit body during spring and summer with average temperatures $17.5^{\circ} \mathrm{C}$ and $27^{\circ} \mathrm{C}$, respectively, showed that the C.albiceps was dominant compared with other Calliphoridae species. In autumn, the results obtained from breeding eggs and larvae clusters showed that the abundance of C.vicina was $70 \%$ more than other species. In the winter, the results confirmed that C.vicina was only active species.

\section{Development of C.vicina and C.albiceps immature stages in laboratory}

The development period for the species C.albiceps was measured in incubator in two constant temperatures of $25^{\circ} \mathrm{C}$ and $30^{\circ} \mathrm{C}$, and $40 \%$ humidity. This period for the species C.vicina was measured in two constant temperatures of $15^{\circ} \mathrm{C}$ and $20^{\circ} \mathrm{C}$, and $70 \%$ humidity. In the case of C.albiceps, as the temperatures increases from $25^{\circ} \mathrm{C}$ to $30^{\circ} \mathrm{C}$, the brooding time as well as the time spent for the next development stages reduce to half. Furthermore, it was found the same pattern for the first larval instar to second instar as well as the second to third instar. The pupa duration at the temperatures of $30^{\circ} \mathrm{C}$ and $25^{\circ} \mathrm{C}$ were 3 and 5 days, respectively. The total development from egg to adult for C.albiceps at $25^{\circ} \mathrm{C}$ and $30^{\circ} \mathrm{C}$ were 11 and 8.5 days, respectively (Table 1 ). For the species C.vicina, the difference in the growth time of first and second larval instar, at temperature $20^{\circ} \mathrm{C}$, was half the time when the temperature was $15^{\circ} \mathrm{C}$. The development of third larval instar include feeding and post feeding stages, took 8 and 5 days at the temperatures $15^{\circ} \mathrm{C}$ and $20^{\circ} \mathrm{C}$, respectively. The maximum difference is associated with the pupal period since it took 18 and 13 days 
Table 1 Development duration and thermal requirements (ADD) of Chrysomya albiceps (second generation) at constant temperatures $(\mathrm{RH}=50 \%$, Photoperiod $=14$ : 10$)$

\begin{tabular}{|c|c|c|c|c|c|}
\hline \multirow[t]{2}{*}{ Life stages } & \multicolumn{2}{|c|}{ Development duration (Day+/-SD) } & \multicolumn{2}{|c|}{$\underline{\operatorname{ADD}\left({ }^{\circ} \mathrm{C}\right)}$} & \multirow[t]{2}{*}{$\mathrm{Dz}\left({ }^{\circ} \mathrm{C}\right)$} \\
\hline & $25^{\circ} \mathrm{C}$ & $30^{\circ} \mathrm{C}$ & $25^{\circ} \mathrm{C}$ & $30^{\circ} \mathrm{C}$ & \\
\hline Egg hatching & $1+/-0.0$ & $0.5-1+/-0.0$ & 15. 28 & 10. $1-20.3$ & 9.72 \\
\hline 1st larval instar (L1) & $1+/-0.0$ & $1+/-0.0$ & 13.86 & 18.86 & 11. 14 \\
\hline 2nd larval instar (L2) & $2+/-0.0$ & $1+/-0.0$ & 24 & 17 & 13 \\
\hline 3rd larval instar (L3) & $3+/-0.0$ & $2+/-0.0$ & 31.56 & 31.04 & 14.48 \\
\hline Pupal stage & $5+/-0.0$ & $3.5+/-0.0$ & 53.41 & 54. 9 & 14.317 \\
\hline First larval instar to adult eclosion & 11 & 7.5 & 105.82 & 109.65 & 15. 38 \\
\hline Egg to Adult eclosion & 12 & $8-8.5$ & 178.68 & 159. 12 & 10. 11 \\
\hline
\end{tabular}

at temperatures $15^{\circ} \mathrm{C}$ and $20^{\circ} \mathrm{C}$, respectively. Overall, the whole period of development from first larval instar to adult for C.vicina at temperatures $15^{\circ} \mathrm{C}$ and $20^{\circ} \mathrm{C}$ lasted 32 and 21 days, respectively (Table 2).

\section{Temperature requirement in laboratory condition}

The results showed that the development period was in inverse proportion to temperature. In other words, as the temperature increases to upper threshold, growth is accelerated and the length of the development period is reduced. During the growth process, the base threshold temperature for any stage was increasing in such a way that the minimum threshold of growth temperatures for the egg to first larval instar, first to second instar, second to third instar, third larval to pupal and pupal to adult were considered as $9.72{ }^{\circ} \mathrm{C}, 11.14^{\circ} \mathrm{C}, 13^{\circ} \mathrm{C}, 14.48{ }^{\circ} \mathrm{C}$ and $14.317{ }^{\circ} \mathrm{C}$, respectively. In C.albiceps, the length of the development of each stage relative to the total development period at the temperatures $25^{\circ} \mathrm{C}$ and $30^{\circ} \mathrm{C}$ were as follows: egg to first larval $(9 \%, 6.25 \%)$, first to second larvae $(9 \%, 12.5 \%)$, second to third larvae $(18 \%, 12.5 \%)$, third larva to pupa $(27 \%, 25 \%)$, pupal to adult stage (45. $5 \%, 44 \%)$ and first larvae to adult was (90\%, 94\%). For C.vicina, the greatest contribution of the development period, in temperatures 15 and $20^{\circ} \mathrm{C}$, is assigned to the pupal to adult period that accounted for 62 and 56 percentage of the total development period, respectively. The development time of third instar larvae to pupa stage were calculated 24 and 25 percentage of the total pre-mature time at $15^{\circ} \mathrm{C}$ and $20^{\circ} \mathrm{C}$ respectively. Also, the development time from egg to the end of third instar larvae were observed about 14.24 and 18.57 percentage of the total time at $15^{\circ} \mathrm{C}$ and $20^{\circ} \mathrm{C}$ respectively. Similar to C.albiceps, the greatest contribution of the development period of C.vicina is assigned to the pupal period. It was quite evident that temperature had a key role, especially in low temperatures, in making significant differences in temperature requirement of growth of ADD in C.vicina at $15^{\circ} \mathrm{C}$ and $20^{\circ} \mathrm{C}$. For C.albiceps, the majority of required ADD was related to the immature period, and the same applied to C.vicina. As the larvae development, the amount of ADD increased too such a way that, at temperatures $15^{\circ} \mathrm{C}$ and $25^{\circ} \mathrm{C}$, the amount of ADD for the third larvae were determined as $104^{\circ} \mathrm{C}$ and $90^{\circ} \mathrm{C}$ respectively, and for the pupal stage, it was similar and equal to $234^{\circ} \mathrm{C}$ (Table 2).

\section{Discussion}

In this study, as other researches (Al-Shareef \& AlQurashi, 2016; Grassberger et al., 2003; Queiroz, 1996; Grassberger \& Reiter, 2001; Augul, 2009) we found that as the temperature increases, the length of the development is shortened. In C.albiceps, the length of larvae stage (first larval to Pupal instar) in $25^{\circ} \mathrm{C}$ and $30^{\circ} \mathrm{C}$ were 6 and 4 days,

Table 2 Development duration and thermal requirements (ADD) of Calliphora vicina (second generation) at constant temperatures $(\mathrm{RH}=70 \%$, Photoperiod $=10: 14)$

\begin{tabular}{|c|c|c|c|c|c|}
\hline \multirow[t]{2}{*}{ Life stages } & \multicolumn{2}{|c|}{ Development duration (Day+/-SD) } & \multicolumn{2}{|c|}{$\mathrm{ADD}\left({ }^{\circ} \mathrm{C}\right)$} & \multirow[t]{2}{*}{$\mathrm{Dz}\left({ }^{\circ} \mathrm{C}\right)$} \\
\hline & $15^{\circ} \mathrm{C}$ & $20^{\circ} \mathrm{C}$ & $15^{\circ} \mathrm{C}$ & $20^{\circ} \mathrm{C}$ & \\
\hline Egg hatching & $2+/-0.0$ & $1+/-0.0$ & 26 & 18 & 2 \\
\hline 1st larval instar (L1) & $2+/-0.0$ & $1+/-0.0$ & 26 & 18 & 2 \\
\hline 2nd larval instar (L2) & $2+/-0.0$ & $1+/-0.0$ & 26 & 18 & 2 \\
\hline 3rd larval instar (L3) & $8+/-0.0$ & $5+/-0.0$ & 104 & 90 & 2 \\
\hline Pupal stage & $18+/-0.0$ & $13+/-0.0$ & 234 & 234 & 2 \\
\hline Egg to adult eclosion & 32 & 21 & 416 & 396 & 2 \\
\hline
\end{tabular}


respectively. Different researchers determined different values for the length of this stage: Velez and Wolff (Velez \& Wolff, 2008) $\left(8-10\right.$ days at $\left.25^{\circ} \mathrm{C}\right)$; Grassberger (Grassberger et al., 2003) (8-10 days); Al-Shareef and AlQurashi (Al-Shareef \& Al-Qurashi, 2016) (6 days); Queiroz (Queiroz, 1996) (5 days at $27^{\circ} \mathrm{C}$ ); Augul and Jassim (Augul, 2009) (3 days at $30^{\circ} \mathrm{C}$ ); AL-Shareef and AlQurashi(Al-Shareef \& Al-Qurashi, 2016) (5 days); Richard et al. (Richards et al., 2008) (5. 5 days); Shiravi et al.(Shiravi et al., 2011) (2-3 days at $\left.28^{\circ} \mathrm{C}\right)$. In our research, the length of the pupal period for C.albiceps at $25^{\circ} \mathrm{C}$ and $30^{\circ} \mathrm{C}$ were determined as 5 and 3. 5 days, respectively. Again, other researchers determined different numbers: Grassberger (Grassberger et al., 2003). 1 and 5.9 days at $25^{\circ} \mathrm{C}$ and $30^{\circ}$ $\mathrm{C}$, respectively; Al-Shareef and Al-Qurashi, (Al-Shareef \& $\mathrm{Al}$-Qurashi, 2016) 5.5 and 4 days at $25^{\circ} \mathrm{C}$ and $30^{\circ} \mathrm{C}$, respectively; Queiroz, (Queiroz, 1996) 4.7 and 3 days at $27^{\circ}$ $\mathrm{C}$ and $32^{\circ} \mathrm{C}$ respectively and Shiravi (Shiravi et al., 2011) (4-6 days at $28^{\circ} \mathrm{C}$ ). In addition, in our study, the length of egg to adult eclosion, at $25^{\circ} \mathrm{C}$ and $30^{\circ} \mathrm{C}$ were determined as 12 and $8-8.5$ days, respectively. Other researchers got the followings: Grassberger (Grassberger et al., 2003) 13 and 9.9 days at $25^{\circ} \mathrm{C}$ and $30^{\circ} \mathrm{C}$; Velez and Wolff (Augul, 2009) (14 days at $25^{\circ} \mathrm{C}$ ); Al-Shareef and Al-Qurashi, (AlShareef \& Al-Qurashi, 2016) 11.5 and 9 days at $25^{\circ} \mathrm{C}$ and $30^{\circ} \mathrm{C}$ respectively; Shiravi et al. (Shiravi et al., 2011) (8-12 days at $28^{\circ} \mathrm{C}$ ); and Queiroz(Queiroz, 1996) (7 days at $32^{\circ}$ C). The figures calculated for the life cycle of the speceis C.albiceps were more similar to the ones obtained in $\mathrm{Al}$ shareef (Al-Shareef \& Al-Qurashi, 2016) and Shiravi (Shiravi et al., 2011) studies and were different from others. The reason seems to be natural. As noted in various studies, inherent biogeographically variation between population (Marchenko, 1989; Donovan et al., 2006; Szpilla, 2010a; Greenberg \& Kunich, 2002) food substrate (Greenberg \& Kunich, 2002; Kounouz \& Kamel, 2017) humidity, population density and other intrinsic factors are considered as the reason of such differences (Faria \& Godoy, 2001; Rosa et al., 2006). It seems that histolysis and histogenesis of the adult organs in immature stage were the reason of the highest thermal requirement of ADD in both $25^{\circ} \mathrm{C}$ and $30^{\circ} \mathrm{C}$, during the pupal period, and the length of this development stage has been mentioned in most researches (Al-Shareef \& Al-Qurashi, 2016; Queiroz, 1996; Bharti, 2009; Defilippo et al., 2013; Donovan et al., 2006; Richards et al., 2008; Augul, 2009; Velez \& Wolff, 2008). Our findings about the life cycle of C.vicina showed that this species will also have shorter life cycle as the temperature increases such a way that at $15^{\circ} \mathrm{C}$, its life cycle, from the egg stage to adult, it took 32 days while at $20^{\circ} \mathrm{C}$, it took 21 days. For this species, other researchers obtained similar results: Reibe et al. (Reibe et al., 2009) at $13^{\circ} \mathrm{C}$ and $20^{\circ} \mathrm{C}, 45$ and 23 days, respectively; Defilippo et al. (Defilippo et al., 2013) at $15^{\circ} \mathrm{C}$ and $20^{\circ} \mathrm{C}, 30.5$ and 20 days, respectively; Bharti (Bharti, 2009) at $20^{\circ} \mathrm{C}$ and $25^{\circ} \mathrm{C}$, 19 and 15. 29 days. The results obtained from our study were more near to the ones obtained from the study done by Defilippo et al. (Defilippo et al., 2013). In terms of rate of development in C.vicina and C.albiceps, the results of this study were compatible with the finding of the studies of Greenberg,(Greenberg, 1991) (Lowne 1890), Defillipo et al (Defilippo et al., 2013) Such a way that the length of post-feeding and pupal periods were determined one third and half the total immature development stage, respectively. The amount of ADD was calculated for C.albiceps at $25^{\circ} \mathrm{C}$ and $30^{\circ} \mathrm{C}$ respectively, as 179 and 159 which correspond to the results obtained from the study done by Shiravi et al. (Shiravi et al., 2011) the amount of ADD, at $28^{\circ} \mathrm{C}$, was calculated between 130 and 195 DD. Moreover, the amount of ADD for the first larvae instar to adult of this species at $25^{\circ} \mathrm{C}$ and $30^{\circ} \mathrm{C}$ was calculated as $96^{\circ} \mathrm{C}$ and $110^{\circ} \mathrm{C}$ respectively. In the study done by AL-Shareef, (Al-Shareef \& Al-Qurashi, 2016) the length of this period, at the same temperature, has been determined as 110 and 129. The life cycle of these species depends on some other factors, such as the geographic differences of population and genetics. Actually, the rate of development in necrophagous insects is the response of organisms to their thermal environment. Determining the rate of development of forensically important insects such as C.albiceps and C.vicina can give us valuable information concerning the circumstance of the death including the postmortem interval.

\section{Conclusion}

This study emphasizes the importance of determining of developmental data for these species and other first colonizers on the carcass in each geographical region. The results of this study will be usable to estimate of the PMI in the western of Iran and similar regions.

\section{Acknowledgments \\ This work was supported by Tehran University of Medical Sciences, Tehran, Iran project No.34233. \\ Funding \\ This work was supported by Tehran University of Medical Sciences, Tehran, Iran project No.34233.}

\section{Availability of data and materials \\ They are available.}

\section{Authors' contributions}

MS Sampling of insects on carcass and samples breeding. YR Managing of Project and writing of Project and Manuscript. MO Help in writing the project. OC Assistance in data analysis. ML Assistance in field and Lab. SR Assistance in Lab and editing of paper. All authors read and approved the final manuscript.

Ethics approval and consent to participate

Necessary ethical approval was obtained from School of Public Health, Tehran University of Medical Sciences Ethics Committee, code No.IR.TUMS.SPH.REC.1395.1634. 


\section{Consent for publication}

All authors have complete consent to print article information.

\section{Competing interests}

The authors declare that they have no competing interests.

\section{Publisher's Note}

Springer Nature remains neutral with regard to jurisdictional claims in published maps and institutional affiliations.

\section{Author details}

'Department of Medical Entomology \& Vector Control, School of Public Health, Tehran University of Medical Sciences(TUMS), Tehran, Iran. ${ }^{2}$ Department of Mathematical, Statistics and Probability, Malayer University, Malayer, Iran. ${ }^{3}$ Departments of Public Health and Health Research Center, Kermanshah University of Medical Sciences, Kermanshah, Iran. ${ }^{4}$ National Institute for Medical Research Development(NIMAD), Tehran, Iran.

\section{Received: 7 October 2017 Accepted: 14 March 2018}

\section{Published online: 20 March 2018}

\section{References}

Al-Mesbah H, Al-Osaimi Z, El-Azazy OME (2011) Forensic entomology in Kuwait: the first case report. Forensic Sci Int 206:25-26

Al-Shareef LAH, Al-Qurashi SID (2016) Study of some biological aspects of the blowfly Chrysomya albiceps (Wiedemann 1819) (Diptera: Calliphoridae) in Jeddah, Saudi Arabia. Egyptian Journal of Forensic Sciences 6:11-16

Ames C, Turner BD (2003) Low temperature episodes in the development of blowflies: implications for postmortem interval estimation. Med Vet Entomol 17:178-186

Anderson G (2000) Minimum and maximum development rates of some forensically important Calliphoridae (Diptera). J Forensic Sci 45:824-832

Augul RS, Jassim SY. Study of some biological and ecological aspects of the Chrysomya albiceps (Wiedemann) (Diptera: Calliphoridae). J Al-Anbar Univ Pure Sci 2009; 3(1)

Bansode SA, More VR, Zambare SP (2016) Effect of different constant temperature on the life cycle of a fly of forensic importance Lucilia cuprina. Entomol Ornithol Herpetol 5:183. https://doi.org/10.4172/2161-0983.1000183

Bharti M (2009) Studies on life cycles of forensically important flies, Calliphora vicina and Musca domestica nebulo at different temperatures. J ent Res 33(3): 273-275

Bharti M, Singh D (2003) Insect faunal succession on decaying rabbit carcasses in Punjab, India. J Forensic Sci 48:1133-1143

Chua TH (2013) Use of temperature model in estimating postmortem interval in forensic entomology. Int J Entomol Res 1:11-15

Davies L, Ratcliffe GG (1994) Development rates of some pre-adult stages in blowflies with reference to low temperatures. Med Vet Entomol 8:245-254

Defilippo F, Rubini S, Dottori M, Bonilauri P (2013) Effect of temperature on six different developmental landmarks within the Pupal stage of the forensically important blowfly Calliphora vicina (Robineau-Desvoidy). J Forensic Sci. https://doi.org/10.1111/1556-4029.12199. Available online at: onlinelibrary. wiley.com

Donovan SE, Hall MJR, Turner BD, Moncrieff CB (2006) Larval growth rates of the blowfly, Calliphora vicina, over a range of temperatures. Med Vet Entomol 20: 106-114

Erzinclioglu Z (1996) Blowflies. The Richmond Publishing Co, Ltd

Faria LDB, Godoy WAC (2001) Prey choice by facultative predator larvae of Chrysomya albiceps (Diptera: Calliphoridae). Mem Inst Oswaldo Cruz, Rio de Janeiro 96(6):875-878

Faucherre J, Cherix D, Wyss C (1999) Behavior of Calliphora vicina(Diptera, Calliphoridae) under extreme conditions. Journal of insect behavior 12:687-690

Gennard DE (2007) Forensic entomology: an introduction. John Wiley \& Sons Ltd, Chichester

Grassberger M, Friedrich E, Reiter C (2003) The blowfly Chrysomya albiceps (Wiedemann) (Diptera: Calliphoridae) as a new indicator in Central Europe. Int J Legal Med 117:75-81

Grassberger M, Reiter C (2001) Effect of temperature on Lucilia sericata (Diptera: Calliphoridae) development with special reference to the isomegalenand isomorphen-diagram. Forensic Sci Int 120(1-2):32-36

Greenberg B (1991) Flies as forensic indicators. J Med Entomol 28(5):565-577
Greenberg B, Kunich JC (2002) Entomology and the law: flies as forensic indicators. Cambridge University Press, Cambridge, United Kingdom

Haskell NH, Lord WD, Byrd JF. Collection of entomological evidence during death investigations. Forensic Entomology: The Utility of Arthropods in Legal Investigations (ed. by J. H. Byrd and J. L. Castner), Florida. CRC Press; 2000. pp. $81-120$

Kamal AS (1958) Comparative study of thirteen species of sarcosaprophagous Calliphoridae and Sarcophagidae (Diptera) I. Bionomics. Ann Entomol Soc Am 51:261-271

Kounouz SH, Kamel L (2017) Development of Calliphora vicina (RobineauDesvoid) (Diptera: Calliphoridae) under different biotic and abiotic conditions. Journal of Entomology and Zoology Studies 5(1):683-691

Kumara TK, Abu Hassan A, Bhupinder S (2017) Forensic Entomology-Insect Development and Temperature. Journal of Forensic Sciences \& Criminal Investigation 4(2):555636. https://doi.org/10.19080/JFSCI.2017.04.555636

Lowne B (1890) The anatomy, physiology, morphology and development of the blowfly. RH Porter, London

Marchenko MI (1989) Method of retrospective determination of insect development onset in a cadaver. Sud Med Ekspert 32(1):17-20

Oshaghi MA, Maleki-Ravasan N, Javadian E, Rassi Y, Sadraei J, Enayati AA et al (2009) Application of predictive degree day model for field development of sand fly vectors of visceral leishmaniasis in northwest of Iran. J Vector Borne Dis 46(4):247-254

Queiroz MMC (1996) Temperature requirement of Chrysomya albiceps (Wiedemann, 1819) (Diptera: Calliphoridae) under laboratory conditions. Mem Inst Oswaldo Cruz 91(6):785-788

Reibe S, Schmitz J, Madea B (2009) Molecular identification of forensically important blowfly species (Diptera: Calliphoridae) from Germany. Parasitol Res 106(1):257-261

Richards CS, Paterson ID, Villet MH (2008) Estimating the age of immature Chrysomya albiceps (Diptera: Calliphoridae), correcting for temperature and geographical latitude. Int J Legal Med 122:271-279

Rosa GS, Carvalho LRD, Reis SFD, Godoy WAC (2006) The dynamics of Intraguild predation in Chrysomya albiceps Wied. (Diptera: Calliphoridae): interactions between instars and species under different abundances of food. Neotropical Entomology 35(6):775-780

Shiravi AH, Mostafavi R, Akbarzadeh K, Oshaghi MA (2011) Temperature requirements of some common forensically important blow and flesh flies (Diptera) under laboratory conditions. Iran J Arthropoda Borne Dis 5(1):54-62

Smith KGVA (1986) Manual of forensic entomology. London. In: UK: the British museum (natural history) and Cornell University press

Szpila K, Matuszewski S, Bajerlein D, Konwerski S (2008) Chrysomya albiceps (WIEDEMANN, 1819), a forensically important blowfly (Diptera: Calliphoridae) new for the polish fauna. Polish Journal of Entomology 77:351-355

Szpilla K. Key for identification of European and Mediterranean blowflies (Diptera, Calliphoridae) of forensic importance Adult flies 2010a

Szpilla K. Key for identification of European and Mediterranean blowflies (Diptera, Calliphoridae) of forensic importance third instars 2010b

Tabor KL, Brewster CC, Fell RD (2004) Analysis of the successional patterns of insects on carrion in Southwest Virginia. J Med Entomol 41:785-795

Velez CM, Wolff M (2008) Rearing five species of dipteral (Calliphoridae) of forensic importance in Colombia in semi controlled field conditions. Papeis Avuloso de Zoologia (Sao Paulo) 48(6):41-47

Vinogradova EB, Reznik SY (2015) Influence of constant and changing temperatures on the larval development of Calliphora vicina (Diptera: Calliphoridae). Acta Soc Zool Bohem 79:149-154

Williams H (1984) A model for the aging of fly larvae in forensic entomology. Forensic Sci Int 25:191-199 